\title{
ELECTRON TRANSPORT IN A COUPLED GaN/AIN/GaN CHANNEL OF NITRIDE HFET
}

\author{
L. Ardaravičius, O. Kiprijanovič, and J. Liberis \\ Center for Physical Sciences and Technology, Sauletekio 3, LT-10257 Vilnius, Lithuania \\ E-mail: linas.ardaravicius@ftmc.lt
}

Received 1 June 2016; revised 30 July 2016; accepted 23 September 2016

\begin{abstract}
Longitudinal hot-electron transport is investigated for the alloy-free AlGaN/AlN/\{GaN/AlN/GaN\} heterostructure at electric fields up to $380 \mathrm{kV} / \mathrm{cm}$. The structure featured a coupled channel with a camelback electron density profile. The hot-electron drift velocity in the coupled channel is estimated as $\sim 1.5 \times 10^{7} \mathrm{~cm} / \mathrm{s}$ and is $\sim 50 \%$ higher as compared with the standard AlN-spacer GaN 2DEG channel. The HFET with the pristine 2DEG density of $1.75 \times 10^{13} \mathrm{~cm}^{-2}$ confined in the coupled channel demonstrates the optimal frequency performance in terms of electron velocity at a relatively low gate bias of $V_{\mathrm{GS}}=-1.75 \mathrm{~V}$. These results are consistent with the ultra-fast decay of hot phonons.
\end{abstract}

Keywords: nitride heterostructure, HFET, electron drift velocity, hot phonons, high electric fields

PACS: 72.10.Di, 72.20.Ht, 72.20.Fr, 72.30.+q, 85.30.Tv

\section{Introduction}

Gallium nitride heterostructure field-effect transistors (HFETs) are very promising for high-speed high-power applications [1]. Recently, HFETs with current unity gain cut-off frequency of $400 \mathrm{GHz}$ were reported [2]. The cut-off frequency is related to the average carrier velocity in a two-dimensional electron gas (2DEG) channel. The experimental reports show that the room temperature electron velocity values in GaN-based 2DEG channels lie between $(1-3) \times 10^{7} \mathrm{~cm} / \mathrm{s}[3-9]$. While the low-field electron mobility tends to decrease as the density of 2DEG increases, the high-field drift velocity is not a monotonous function of the density [10]. The highest value is reached at $\sim(1.0 \pm 0.1) \times 10^{13} \mathrm{~cm}^{-2}$ electron density in agreement with the resonance decay of hot phonons (non-equilibrium longitudinal optical (LO) phonons): the resonance takes place in the vicinity of the crossover of dispersion curves for initially noninteracting LO phonons and plasmons. The plasmonassisted decay of LO phonons has been confirmed experimentally [11-13]. For GaN-based 2DEG channels the hot LO phonon lifetime is the shortest near
$7 \times 10^{12} \mathrm{~cm}^{-2}$ at low electric fields, in reasonable agreement with the resonance condition. Also, as expected, the resonance 2DEG density increases with the applied electric field [10, 14] because the plasma frequency decreases when the bulk density of the electron gas decreases under heating.

The optimal 2DEG density for frequency performance is a compromise. Experimental results illustrate that the cut-off frequency for standard GaN-based HFETs is $f_{T}=205 \mathrm{GHz}$ for $n_{2 \mathrm{D}}=2.4 \times 10^{13} \mathrm{~cm}^{-2}$ [15] and $f_{T}=300 \mathrm{GHz}$ for $n_{2 \mathrm{D}}=1.65 \times 10^{13} \mathrm{~cm}^{-2}$ [16]. Because the optimal frequency performance takes place at a negative gate bias, the $2 \mathrm{DEG}$ density in the channel under the biased gate electrode is lower than the pristine 2DEG density in the as-grown heterostructures. The estimated effective density under the gate (namely, $(1.0 \pm 0.1) \times 10^{13} \mathrm{~cm}^{-2}$ in the standard GaN 2DEG channel at the optimum bias for the cut-off frequency) is consistent with the condition for ultrafast decay of hot phonons [17].

The signature of the LO-phonon-plasmon crossover manifests itself in experiments on electron drift velocity [10], transistor cut-off frequency [18], and transistor degradation: the electron drift velocity is the highest, 
the transistor operation is the fastest, the phase noise lev$\mathrm{el}$ is the lowest, and the device degradation is the slowest inside the electron density window where the hotphonon lifetime acquires the shortest values [17, 19].

It should be noted that the LO-phonon-plasmon interaction and the associated hot LO phonon decay are determined by the profile of vertical electron distribution rather than the total number of electrons in the channel (proportional to the 2D density). Hence, a faster decay of hot phonons can be achieved at a higher 2D density - even if it exceeds the resonance value at low electric fields - when the vertical distribution of electrons is spread out. For example, application of a high field can reduce $3 \mathrm{D}$ density and make the profile closer to the resonance one. Calculations reveal the reduced $3 \mathrm{D}$ peak density at elevated hot-electron temperature [20], which in turn has an impact on the associated LOphonon-plasmon resonance. However, it might not be practical to heat the electrons sufficiently in order to reduce their peak density to the resonance one without damaging the sample. An alternative solution which does not require electric field to spread the electron distribution is to diminish the 3D density in composite channel structures with a camelback electron density profile [21-26.

In this work the current-voltage dependence was measured by the nanosecond-pulsed voltage technique in alloy-free coupled channel AlGaN/AlN/ $\{\mathrm{GaN} / \mathrm{AlN} / \mathrm{GaN}\}$ heterostructures with a camelback electron density profile. The estimated drift velocity and the performance of a coupled channel nitride HFET is discussed in terms of plausible plasmonassisted hot-phonon decay.

\section{Samples}

The investigated heterostructures were grown on csapphire substrates in a low-pressure custom-designed Organo-Metallic Vapour Phase Epitaxy (OMVPE) system at Virginia Commonwealth University (USA). The sample growth and processing procedure is described in Ref. [23]. The schematic diagram resulting in an alloy-free coupled channel heterostructure is shown in Fig. 1. Figure 2 presents the 3D electron density $n_{3 \mathrm{D}}\left(\mathrm{cm}^{-3}\right)$ profile versus the distance $(\mathrm{nm})$ estimated from capacitance-voltage $(\mathrm{CV})$ measurements at a frequency of $1 \mathrm{MHz}$ for the AlGaN/AIN/\{GaN/AlN/ $\mathrm{GaN}\}$ heterostructure at room temperature (blue solid line). The profile was calculated from the CV measurements by using the expression given in Ref. [18]: $n_{3 \mathrm{D}}=-2\left\{\epsilon e A^{2} \mathrm{~d}\left(1 / C^{2}\right) / \mathrm{d} V\right\}$, where $\epsilon$ is the dielectric constant, $e$ is the elementary charge, and $A$ is the area of the diode. It is clearly seen that the alloy-free struc- ture exhibits a camelback density profile (coupled channel) at the equilibrium (zero electric field).

\#3584

\begin{tabular}{|c|}
\hline GaN $-2 \mathrm{~nm}$ \\
\hline AIGaN: $20 \mathrm{~nm} 28.5 \% \mathrm{AI}$ \\
\hline AIN $-1 \mathrm{~nm}$ \\
\hline GaN: $4 \mathrm{~nm}$ \\
\hline AIN $-1 \mathrm{~nm}$ \\
\hline GaN $-3.5 \mu \mathrm{m}$ \\
\hline AIN - 350 nm \\
\hline Sapphire \\
\hline
\end{tabular}

Fig. 1. A schematic view of an alloy-free coupled channel AlGaN/AlN/\{GaN/AlN/GaN\} heterostructure.

\section{Experimental results and discussion}

\subsection{Low-field electron mobility, current-voltage dependence}

Electron transport measurements were carried out on two-electrode samples taken from TLM (Transmission Line Model) structures of width $\omega=240 \mu \mathrm{m}$. The contact resistance $R_{c}$ was estimated at low electric fields from the dependence of the sample resistance $R$ on the channel length $L$. The low-field mobility $\mu_{\mathrm{M}}$ was deduced from magneto-resistance data, and the 2DEG electron density $n_{2 \mathrm{DM}}$ was estimated as $n_{2 \mathrm{DM}}=L / R e \mu_{\mathrm{M}} \omega$, where $e$ is the elementary

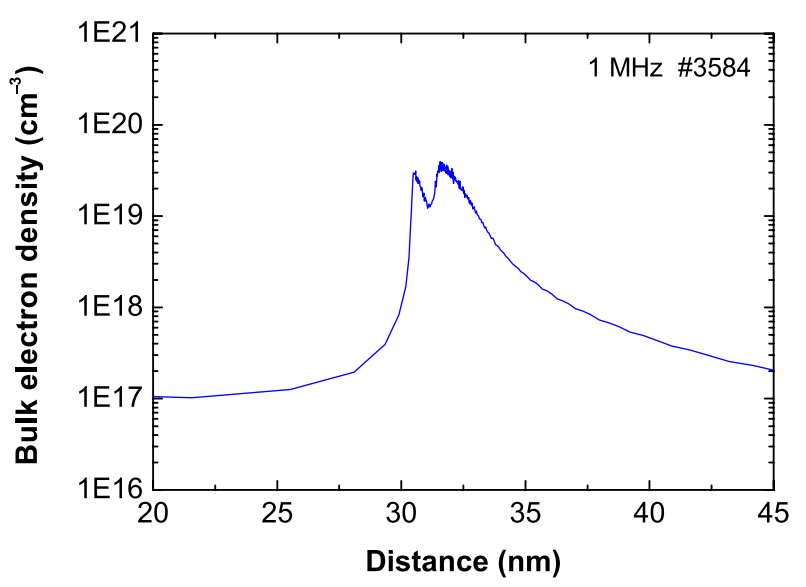

Fig. 2. 3D electron density $\left(\mathrm{cm}^{-3}\right)$ profile versus distance (nm) estimated from CV measurements for the sample (blue solid line online) with a coupled channel. 
Table 1. 2DEG density from CV, magneto-resistance, Hall measurements and magneto-resistive, Hall mobility for a coupled $\{\mathrm{AlN} / \mathrm{GaN} / \mathrm{AlN}\}$ channel and single AlN-spacer GaN-based channel [4] at room temperature.

\begin{tabular}{cccccc}
\hline Structure & $\begin{array}{c}n_{2 \mathrm{DCV}} \\
\times 10^{13} \mathrm{~cm}^{-2}\end{array}$ & $\begin{array}{c}n_{2 \mathrm{DM}} \\
\times 10^{13} \mathrm{~cm}^{-2}\end{array}$ & $\begin{array}{c}n_{2 \mathrm{DHall}} \\
\times 10^{13} \mathrm{~cm}^{-2}\end{array}$ & $\begin{array}{c}\mu_{\mathrm{M}} \\
\mathrm{cm}^{2} / \mathrm{Vs}\end{array}$ & $\begin{array}{c}\mu_{\text {Hall }} \\
\mathrm{cm}^{2} / \mathrm{Vs}\end{array}$ \\
\hline This work & 0.72 & 0.6 & $1.3-1.75$ & 1750 & 1410 \\
\hline$[4]$ & - & - & 1.0 & - & 1152 \\
\hline
\end{tabular}

charge. The sheet electron density was also estimated as $n_{2 \mathrm{DCV}}=0.72 \times 10^{13} \mathrm{~cm}^{-2}$ through the integration of the density profile from CV measurements (Fig. 2) for the alloy-free coupled channel. It is worth noting that the magneto-resistive mobility was estimated on the same TLM pattern where the high-field transport was studied, which is critically important. Hall mobility was measured before TLM processing. Hall mobility values were lower than that obtained from magneto-resistance measurements (Table 1). The discrepancy may arise because of the wafer nonuniformity. The Hall and TLM sample may not correspond to the same radial position. The channel magneto-resistive mobility $\mu_{\mathrm{M}}$ was thought to be the best choice to evaluate the $2 \mathrm{DEG}$ density which was taken to estimate the electron drift velocity. If no $\mu_{\mathrm{M}}$ data was available, Hall mobility values were used.

The nanosecond pulsed technique [27] was applied to study high-field transport at room temperature. The electric field was estimated as $E=\left(V-I R_{c}\right) / L$ where $V$ is the voltage, $I$ is the current, and $R_{c}$ is the total contact resistance. The data for evaluating the current and the voltage drop along the channel were obtained from the oscilloscope amplitudes when either a gauge resistor or the sample under test was present in the circuit.

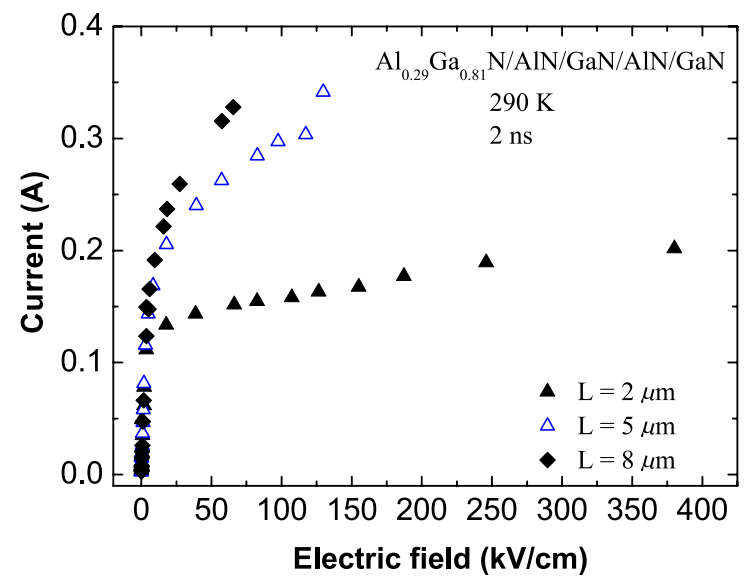

Fig. 3. The current-field dependences for an alloy-free coupled channel AlGaN/AlN/\{GaN/AlN/GaN\} heterostructure. Diamonds stand for $L=8 \mu \mathrm{m}$, empty triangles for $L=5 \mu \mathrm{m}$ and full triangles for $L=2 \mu \mathrm{m}$. Voltage pulse duration is $2 \mathrm{~ns}$.
The pulsed current-field characteristics measured for the alloy-free AlGaN/AlN/\{GaN/AlN/GaN\} structures are shown in Fig. 3. The use of short nanosecond pulses of voltage ( $2 \mathrm{~ns})$ and short channels $(2 \mu \mathrm{m})$ enabled us to reach $380 \mathrm{kV} / \mathrm{cm}$ electric field (Fig. 3, full triangles). The maximum current attained was $0.35 \mathrm{~A}$ for the $L=5 \mu \mathrm{m}$ sample (Fig. 3, empty triangles).

\subsection{Drift velocity, optimal conditions for HFET} frequency performance

The hot-electron drift velocity is determined according to the simple relation under assumptions of uniform electric field and no change in the electron density due to the applied field: $v_{\mathrm{dr}}=I /\left(e n_{2 \mathrm{DM}} \omega\right)$. Figure 4 shows that the drift velocity in the $2 \mu \mathrm{m}$ coupled channel at the highest field $(380 \mathrm{kV} / \mathrm{cm})$ is relatively low $\left(0.8 \times 10^{7} \mathrm{~cm} / \mathrm{s}\right.$, stars $)$ and is comparable with a single $\mathrm{GaN}$ channel with an electron density of $9.5 \times 10^{12} \mathrm{~cm}^{-2}$ [9]. The $5 \mu \mathrm{m}$ long [GaN/AlN/ $\mathrm{GaN}\}$ coupled channel reaches a drift velocity of $1.5 \times 10^{7} \mathrm{~cm} / \mathrm{s}$ at $130 \mathrm{kV} \mathrm{cm} / \mathrm{s}$ (triangles). The maximum velocity attained in the alloy-free coupled channel is approximately the same as in the alloycontaining dual channel made from $\left\{\mathrm{Al}_{0.1} \mathrm{Ga}_{0.9} \mathrm{~N} /\right.$ $\mathrm{GaN}$ \} [22]. This is a strong argument that alloy

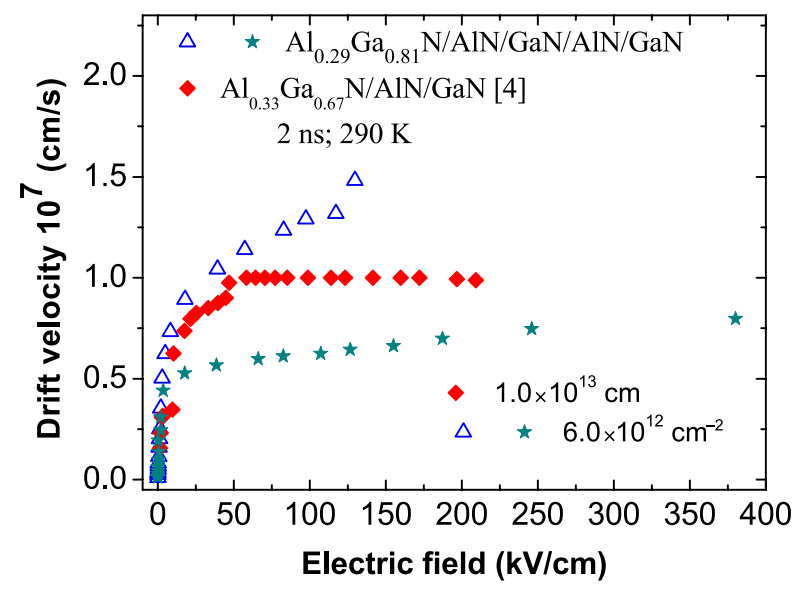

Fig. 4. Room temperature dependence of the drift velocity on the electric field for the alloy-free coupled $\{\mathrm{GaN} /$ AlN/GaN $\}$ channels $(L=5 \mu \mathrm{m}$, blue triangles; $L=2 \mu \mathrm{m}$, stars) and single AlN-spacer GaN-based 2DEG channel ( $L=5 \mu \mathrm{m}$, diamonds [4]). Voltage pulse duration is $2 \mathrm{~ns}$. 
scattering does not play a significant role in camelback channels. Also, the maximum attained drift velocity in the alloy-free coupled channel exceeds that in a standard AlN-spacer single GaN-based 2DEG channel by $50 \%$ [4]. Despite the fact that the velocity in the coupled channel is twice lower than the maximum drift velocity measured in the single GaN 2DEG channel [Ø], for similar electron densities $\left(6 \times 10^{12} \mathrm{~cm}^{-2}\right)$ the velocity in the coupled channel is $50 \%$ higher than in the single GaN 2DEG channel [9].

Let us use the plasmon-assisted hot-phonon decay concept to discuss the observed electron velocity. As mentioned earlier, the hot-phonon lifetime reaches the minimum value and the associated resonance takes place at the electron sheet density near $7 \times 10^{12} \mathrm{~cm}^{-2}$ at low electric fields in GaN 2DEG channels [20]. The drift velocity in the coupled channel can be high because it has a similar electron density (6$\left.7 \times 10^{12} \mathrm{~cm}^{-2}\right)$ and the hot-phonon lifetime estimated from microwave noise measurements is short ( $15 \mathrm{fs}$ at $50 \mathrm{kV} / \mathrm{cm}$ ). It is known from the Monte Carlo simulation [ [4] that the shorter the lifetime is, the faster hotphonon decay and the higher the electron velocity are. For the standard AlN-spacer single GaN-based 2DEG

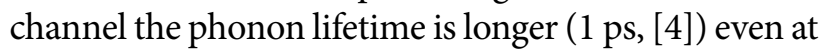
high electric fields as compared to that in the coupled channel, and this causes the reduction in drift velocity (Fig. 4, diamonds).

Let us consider the frequency performance of HFETs processed from the heterostructures with different pristine (initial) 2DEG density measured before transistor processing. In agreement with the concept of an optimum electron density window, a higher negative gate voltage must be applied if the initial 2DEG density is higher. Thus, the optimal frequency performance calls for a reduced effective sheet density under the biased gate in the channel, namely, $1.0 \times 10^{13} \mathrm{~cm}^{-2}[19]$.

The alloy-free coupled $\{\mathrm{GaN} / \mathrm{AlN} / \mathrm{GaN}\}$ channel is promising for its improved low-field transport properties. When the pristine electron density exceeds the resonance value, the resonance can be tuned in with a variable negative bias applied to the gate of a nitride HFET [17]. The HFET with a pristine 2DEG density of $1.75 \times 10^{13} \mathrm{~cm}^{-2}$ in the alloy-free coupled GaN/AlN/GaN channel demonstrates the optimal frequency performance in terms of electron velocity $\left(f_{T}=8.6 \mathrm{GHz}\right.$ for $L_{\mathrm{g}}=1 \mu \mathrm{m} ; V_{\mathrm{DS}}=15 \mathrm{~V}$, where $L_{\mathrm{g}}$ is gate length, and $V_{\mathrm{DS}}^{\mathrm{g}}$ is drain-source voltage) at a relatively low gate bias of $V_{\mathrm{GS}}=-1.75 \mathrm{~V}$, while single-channel HFETs typically require a higher gate bias $\left(-2.9 \mathrm{~V}\right.$ at $\left.1.75 \times 10^{13} \mathrm{~cm}^{-2}[28]\right)$. Among other advantages, the ability to tune into the resonance with a lower gate bias is potentially useful for reducing gate leakage currents.

\section{Conclusions}

Longitudinal hot-electron transport is studied in a coupled $\{\mathrm{GaN} / \mathrm{AlN} / \mathrm{GaN}\}$ channel with a vertically dispersed quasi two-dimensional electron gas. In this alloy-free coupled channel, the highest velocity reaches $\sim 1.5 \times 10^{7} \mathrm{~cm} / \mathrm{s}$ at $130 \mathrm{kV} / \mathrm{cm}$ and exceeds the corresponding values in a standard single $\mathrm{AlN}$-spacer GaN-channel heterostructure by $50 \%$. The high-field drift velocity observed for a particular electron density $\left(\sim 6-7 \times 10^{12} \mathrm{~cm}^{-2}\right)$ is consistent with the ultra-fast decay of hot phonons. No negative differential resistance is observed within the investigated electric field range $(<400 \mathrm{kV} / \mathrm{cm})$. A coupled channel nitride HFET demonstrates the optimal frequency performance at a relatively low gate bias.

\section{Acknowledgements}

This research is funded by the Research Council of Lithuania (Grant No. APP-5/2016). Discussions with Dr. V. Avrutin, Dr. R. A. Ferreyra, Prof. H. Morkoç, and Prof. A. Matulionis are greatly acknowledged. Authors are thankful to Dr. E. Šermukšnis for the C-V profile measurements. The authors are also grateful to the Virginia Commonwealth University Microelectronics Materials and Device Laboratory for the nitride samples.

\section{References}

[1] H. Morkoç, Nitride Semiconductor Devices: Fundamentals and Applications (Wiley-VCH, Weinheim, 2013).

[2] Y. Yue, Z. Hu, J. Guo, B.S. Rodriguez, G. Li, R. Wang, F. Faria, B. Song, X. Gao, S. Guo, T. Kosel, G. Snider, P. Fay, D. Jena, and H.G. Xing, Ultrascaled InAlN/GaN high electron mobility transistors with cutoff frequency of $400 \mathrm{GHz}$, Jpn. J. Appl. Phys. 52, 08JN14 (2013).

[3] C.H. Oxley and M.J. Uren, Measurements of unity gain cutoff frequency and saturation velocity of a GaN HEMT transistor, IEEE Trans. Electron Dev. 52, 165-169 (2005).

[4] L. Ardaravičius, M. Ramonas, O. Kiprijanovič, J. Liberis, A. Matulionis, L.F. Eastman, J.R. Shealy, $\mathrm{X}$. Chen, and Y.J. Sun, Comparative analysis of hot electron transport in $\mathrm{AlGaN} / \mathrm{GaN}$ and $\mathrm{AlGaN} /$ AlN/GaN 2DEG channels, Phys. Status Solidi A 202, 808-811 (2005).

[5] J.M. Barker, D.K. Ferry, S.M. Goodnick, D.D. Koleske, A. Allerman, and R.J. Shul, High field 
transport in GaN/AlGaN heterostructures, J. Vac. Sci. Technol. B 22, 2045-2050 (2004).

[6] B.A. Danilchenko, S.E. Zelensky, E. Drok, S.A. Vitusevich, S.V. Danylyuk, N. Klein, H. Lüth, A.E. Belyaev, and V.A. Kochelap, Hot-electron transport in AlGaN/ GaN two-dimensional conducting channels, Appl. Phys. Lett. 85, 5421-5423 (2004).

[7] J.M. Barker, D.K. Ferry, D.D. Koleske, and R.J. Shul, Bulk GaN and AlGaN/GaN heterostructure drift velocity measurements and comparison to theoretical models, J. Appl. Phys. 97, 063705 (2005).

[8] L. Ardaravičius, M. Ramonas, J. Liberis, O. Kiprijanovič, A. Matulionis, J. Xie, M. Wu, J.H. Leach, and $\mathrm{H}$. Morkoç, Electron drift velocity in latticematched AlInN/AlN/GaN channel at high electric fields, J. Appl. Phys. 106, 073708 (2009).

[9] S. Bajaj, O.F. Shoron, P.S. Park, S. Krishnamoorthy, F. Akyol, T.-H. Hung, S. Reza, E.M. Chumbes, J. Khurgin, and S. Rajan, Density-dependent electron transport and precise modeling of GaN high electron mobility transistors, Appl. Phys. Lett. 107, 153504 (2015).

[10] L. Ardaravičius, J. Liberis, O. Kiprijanovič, A. Matulionis, $\mathrm{M}$. Wu, and $\mathrm{H}$. Morkoç, Hot-electron drift velocity and hot-phonon decay in AlInN/AlN/ GaN, Phys. Status Solidi RRL 5, 65-67 (2011).

[11]A. Matulionis, Hot phonons in GaN channels for HEMTs, Phys. Status Solidi A 203, 2313-2325 (2006).

[12] K.T. Tsen, J.G. Kiang, D.K. Ferry, and H. Morkoç, Subpicosecond time-resolved Raman studies of LO phonons in GaN: dependence on injected carrier density, Appl. Phys. Lett. 89, 112111 (2006).

[13] A. Matulionis, J. Liberis, I. Matulionienè, M. Ramonas, E. Šermukšnis, J.H. Leach, M. Wu, X. Ni, X. Li, and H. Morkoç, Plasmon-enhanced heat dissipation in GaN-based two-dimensional channels, Appl. Phys. Lett. 95, 192102 (2009).

[14] A. Matulionis, J. Liberis, I. Matulionienè, E. Šermukšnis, J.H. Leach, M. Wu, and H. Morkoç, Novel fluctuation-based approach to optimization of frequency performance and degradation of nitride heterostructure field effect transistors, Phys. Status Solidi A 208, 30-36 (2011).

[15]H. Sun, A.R. Alt, H. Benedickter, E. Feltin, J.-F. Carlin, M. Gonschorek, N. Grandjean, and C.R. Bolognesi, 205-GHz (Al,In)N/GaN HEMTs, IEEE Electron Device Lett. 31, 957-959 (2010).

[16] D.S. Lee, X. Gao, S. Guo, and T. Palacios, InAlN/ GaN HEMTs with AlGaN back barriers, IEEE Electron Device Lett. 32, 617-619 (2011).

[17] A. Matulionis, J. Liberis, E. Šermukšnis, L. Ardaravičius, A. Šimukovič, C. Kayis, C.Y. Zhu, R.A. Ferreyra, V. Avrutin, Ü. Özgür, and H. Morkoç, Window for better reliability of nitride heterostructure field effect transistors, Microelectron. Reliabil. 52, 2149-2152 (2012).
[18]J.H. Leach, C.Y. Zhu, M. Wu, X. Ni, X. Li, J. Xie, Ü. Özgür, H. Morkoç, J. Liberis, E. Šermukšnis, A. Matulionis, T. Paskova, E. Preble, and K.R. Evans, Effect of hot phonon lifetime on electron velocity in InAlN/AlN/GaN heterostructure field effect transistors on bulk GaN substrates, Appl. Phys. Lett. 96, 133505 (2010).

[19]A. Matulionis, Electron density window for best frequency performance, lowest phase noise and slowest degradation of $\mathrm{GaN}$ heterostructure fieldeffect transistors, Semicond. Sci. Technol. 28, 074007 (2013).

[20] A. Matulionis, J. Liberis, I. Matulionienè, M. Ramonas, and E. Šermukšnis, Ultrafast removal of LO-mode heat from a GaN-based two-dimensional channel, Proc. IEEE 98, 111826 (2010).

[21] J.H. Leach, M. Wu, H. Morkoç, J. Liberis, E. Šermukšnis, M. Ramonas, and A. Matulionis, Ultrafast decay of hot phonons in an AlGaN/AlN/ AlGaN/GaN camelback channel, J. Appl. Phys. 110, 104504 (2011).

[22] L. Ardaravičius, O. Kiprijanovič, J. Liberis, A. Matulionis, X. Li, F. Zhang, M. Wu, V. Avrutin, Ü. Özgür, and H. Morkoç, Hot-electron drift velocity in AlGaN/AlN/AlGaN/GaN camelback channel, Semicond. Sci. Technol. 27, 122001 (2012).

[23] R.A. Ferreyra, X. Li, F. Zhang, C. Zhu, N. Izyumskaya, C. Kayis, V. Avrutin, Ü. Özgür, and H. Morkoç, Microwave performance of AlGaN/AlN/ GaN-based single and coupled channels HFETs, Proc. SPIE 8625, 86252B (2013).

[24] R. Tülek, E. Arslan, A. Bayrakli, S. Turhana, S. Gökden, O. Duygulud, A.A. Kaya, T. Firat, A. Teke, and E. Özbay, The effect of GaN thickness inserted between two AlN layers on the transport properties of a lattice matched AlInN/AlN/GaN/ AlN/GaN double channel heterostructure, Thin Solid Films 551, 146-152 (2014).

[25] A. Wille, H. Yacoub, A. Debald, H. Kalisch, and A. Vescan, AlGaN/AlN-GaN-SL HEMTs with multiple 2DEG channels, J. Electron. Mater. 44, 1263-1267 (2015).

[26] E. Arslan, S. Turan, S. Gökden, A. Teke, and E. Özbay, Current-transport mechanisms in the AlInN/ AlN/GaN single-channel and AlInN/AlN/GaN/ AlN/GaN double-channel heterostructures, Thin Solid Films 548, 411-418 (2013).

[27]L. Ardaravičius, O. Kiprijanovič, J. Liberis, A. Matulionis, E. Šermukšnis, R.A. Ferreyra, V. Avrutin, Ü. Özgür, and H. Morkoç, Threshold field for soft damage and electron drift velocity in InGaN twodimensional channels, Semicond. Sci. Technol. 30, 105016 (2015).

[28]D.S. Lee, X. Gao, S. Guo, D. Kopp, P. Fay, and T. Palacios, 300-GHz InAlN/GaN HEMTs with InGaN back barrier, IEEE Electron Device Lett. 32, 1525-1527 (2011). 


\title{
ELEKTRONŲ PERNAŠA NITRIDINIAM LAUKO TRANZISTORIUI SKIRTAME SUSIETAME GaN/AIN/GaN KANALE
}

\author{
L. Ardaravičius, O. Kiprijanovič, J. Liberis
}

Fiziniu ir technologijos mokslu centras, Vilnius, Lietuva

\section{Santrauka}

Eksperimentiškai ištirti su kvazidvimatėmis elektronų dujomis $\{\mathrm{GaN} / \mathrm{AlN} / \mathrm{GaN}\}$ susieti kanalai. Tirtas kanalas suformuotas AlGaN/AlN/GaN/AlN/GaN ìvairialyčiame darinyje, užaugintame MOCVD būdu ant safyro padèklo. Dvimatès elektronų dujos buvo veikiamos išoriniu elektriniu lauku, nukreiptu lygiagrečiai darinio plokštumai (statmenai c ašiai). Nanosekundinè VACH matavimo technika panaudota siekiant sumažinti Džaulio šilumos įtaką. Elektronų dreifo greitis įvertintas darant prielaidą, kad elektronų tankis nuo elektrinio lauko nepriklauso. Nustatyta, kad susietame $\{\mathrm{GaN} / \mathrm{AlN} /$ $\mathrm{GaN}\}$ kanale didžiausias elektronų dreifo greitis yra $1,5 \times 10^{7} \mathrm{~cm} / \mathrm{s}$, kai elektrinio lauko stipris $-130 \mathrm{kV} / \mathrm{cm}$, o tai $50 \%$ viršija dreifo greiti standartiniame GaN dvimačių elektronų dujų kanale, nuo barjero atskirtame tarpiniu AlN sluoksniu. Parodyta, kad susieto nitridų kanalo lauko tranzistorius pasižymi geriausia dažnine charakteristika, kai sklendès ịtampa gana maža. Maksimalus dreifo greitis ir optimali tranzistoriaus veika susietame kanale priklauso nuo ultraspartaus karštųjų optinių fononų suirimo. 